Vol. 2, No.1, Januari - Juni 2017

ISSN : 2502-4736

Fakultas Pertanian UNIVERSITAS TRIDINANTI

PALEMBANG

$\frac{3}{3}$

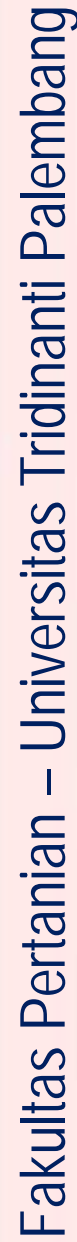

G)
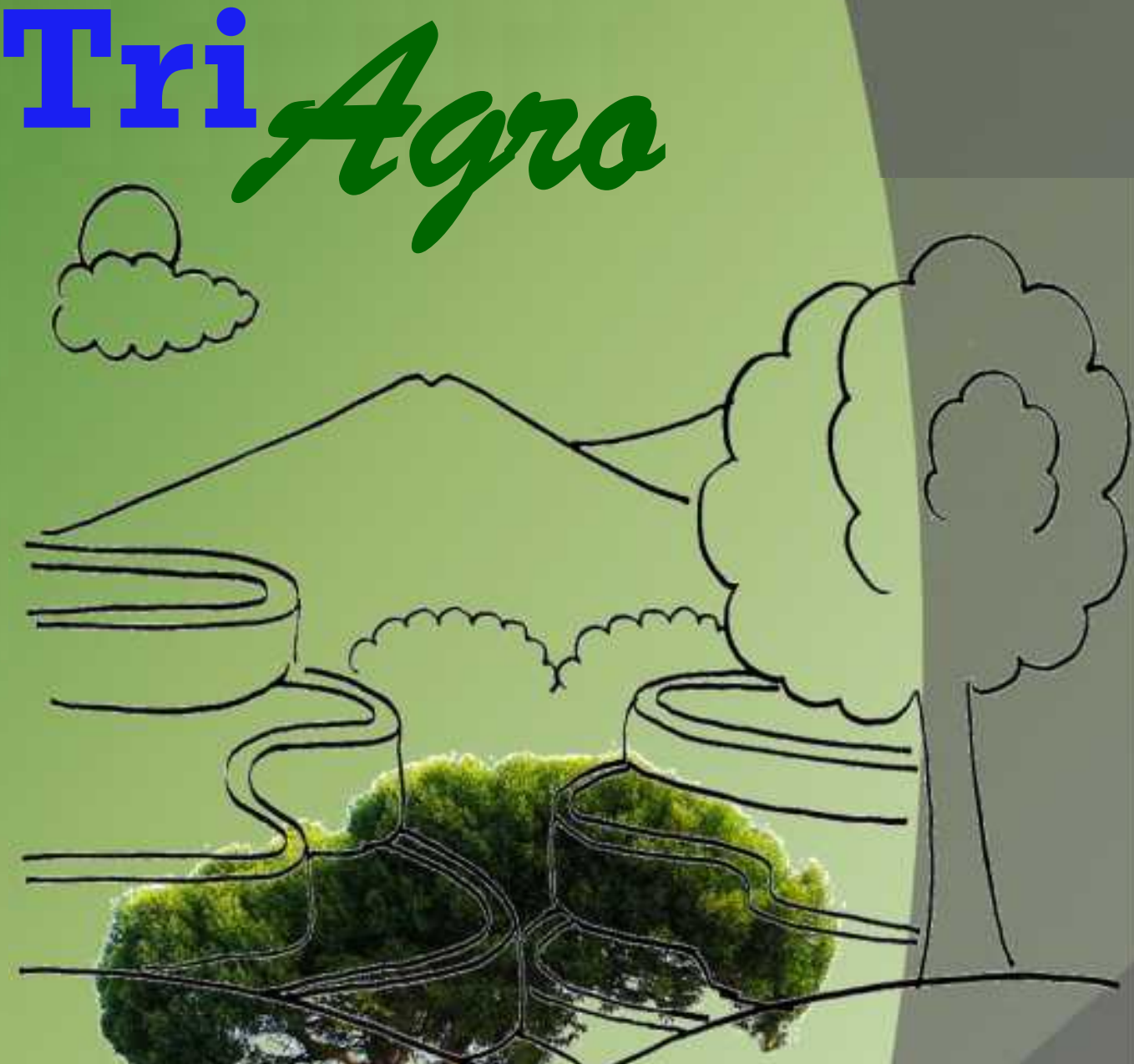

JURNAL Trišrgea

Alamat Redaksi : Fakultas Pertanian Universitas Tridinanti Jalan Kapten Marzuki No, 2446 Kamboja Palembang 30129 Telp. 0711-378387 


\section{Jurnal TRIAGRO}

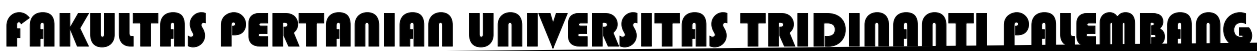

\section{Dewan Redaksi}

Pelindung

Pembina

Pimpinan Umum

Ketua Penyunting

Penyunting Pelaksana

Penyunting Ahli

Dewan Redaksi

Distribusi \& Website
: Dr. Ir. Hj. Manisah MP (Rektor)

: Dr. Nasir Sp. M.Si

: Miranty Trinawaty SP. M.Si

: Prof. Dr. Edizal M.S

- Prof. Dr. Edizal M.S

- Dr.Ir Faridatul Mukminah M.Sc

- Dr. Ir Ruarita RK. MP

: 1. Dr. Ir. Nurmayulis, MP (Universitas Sultan Ageng

Tirtayasa)

2. Dr. Munajat, SP. M.Si (Universitas Baturaja)

:

- Ir. Setiawaty MP

- Ir. Meryanto, M.Si

- Ir. Rostian Nafery, M.Si

- Ir. Ursula Damayanti, MP

- Ir. Ekanovi Aktiva, MM

- Ir. Hj. Yuliantina Azka, MP

: Nova Tri Buyana, Sp 


\section{DAFTAR ISI}

1 RESPON EKSPLAN TANAMAN KENTANG (Solanum tuberrosum L.)

VARIETAS GRANOLA TERHADAP DOSIS PUPUK DAUN DAN KONSENTRASI AIR KELAPA

Rostian Nafery, Zulkarnain Husny, Wendri Pranata *).

2 RESPON PERTUMBUHAN DAN HASIL TANAMAN JAGUNG MANIS

6

(Zea mays saccharata Sturt.) AKIBAT PEMBERIAN BERBAGAI DOSIS

PUPUK ORGANIK CAIR

Ruarita R.K, Ridwan Hanan, Achmad W.A

3 PENGARUH PEMBERIAN ZAT PENGATUR TUMBUH (ZPT)

TERHADAP PERTUMBUHAN DAN HASIL TANAMAN JAGUNG

MANIS (ZEA MAYS SACCHARATA STURT.)

Yuliantina Azka, Meriyanto, Yogi Romadi

PENGARUH PEMBERIAN LIMBAH LUMPUR KERING KELAPA

4 SAWIT TERHADAP PERTUMBUHAN DAN PRODUKSI TANAMAN

TOMAT (Solanum lycopersicum L.)

Bastani Sepindjung, Faridatul Mukminah, Henry Ardiansyah

PENGARUH PEMBERIAN BERBAGAI KONSENTRASI LARUTAN

NUTRISI HIDROPONIK TERHADAP PERTUMBUHAN DAN HASIL

TANAMAN SELADA MERAH (Lactuca sativa L.)DENGAN SISTEM Deep

Flow Technique (DFT)

Meriyanto, Busroni Asnawi, Sari Apriyani

6 PENGARUH PEMBERIAN LARUTAN NUTRISI HIDROPONIK

DENGAN BERBAGAI KONSENTRASI TERHADAP PERTUMBUHAN

DAN HASIL TANAMAN SELADA MERAH (Lactuca sativa L.) DENGAN SISTEM DEEP FLOW TECHNIQUE (DFT)

Meriyanto, Bastani Sepindjung, Rinti Mandasari. 


\section{Pedoman Penulisan Artikel Ilmiah \\ Jurnal TRIAgro \\ Fakultas Pertanian Universitas Tridinanti Palembang}

1. Jurnal ini direncanakan terbit tiga kali dalam setahun, terbuka untuk umum yang ingin mempublikasikan hasil karyanya. Artikel yang ditulis meliputi hasil penelitian di bidang sains.

2. Semua naskah makalah disertai pernyataan bahwa naskah tersebut belum pernah diterbitkan sebelumnya oleh penerbit lain.

3. Setiap naskah yang diterima akan ditinjau/ditelaah oleh ahli dibidangnya sebelum diterbitkan.

4. Naskah tidak dapat diterima jika mengandung unsur politik, komersialisme dan subyektifitas yang berlebihan.

5. Simbol dan terminologi yang digunakan adalah simbol dan terminologi yang lazim digunakan di bidang keahlian masin-masing.

6. Penulis menyetujui untuk mengalihkan hak ciptanya ke redaksi, jika naskahnya diterima untuk diterbitkan.

7. Artikel ditulis dalam bahasa Indonesia atau Inggris. Minimal 10 halaman dan maksimal 15 halaman, termasuk daftar pustaka dan lampiran : ukuran kertas A4, spasi 1,5, margin kiri $4 \mathrm{~cm}$, margin kanan, atas dan bawah masing-masing $3 \mathrm{~cm}$, menggunakan Times New Roman Font 11.

8. Artikel diketik dengan program MS Word, penulis dimohon mengirimkan satu print out dan satu CD yang berisi artikel, cantumkan alamat email dan no telepon/hp penulis untuk keperluan konfirmasi tentang tulisan yang dikirimkan ke redaksi.

9. Artikel dilengkapi :

Abstrak tidak lebih dari 200 kata dengan kata-kata kunci, biodata singkat penulis dan identitas penelitian dicantumkan sebagai cat kaki pada halaman pertma artikel.

10. Penulisan daftar pustaka mengikuti penulisan yang baik dan benar 


\section{KATA PENGANTAR}

Terima kasih atas berkah Tuhan Yang Maha Kuasa dan Rahmat-Nya, maka Jurnal TriAgro Fakultas Pertanian Universitas Tridinanti Palembang ini dapat diterbitkan. Jurnal ini diharapkan dapat menampung informasi dunia pertanian modern dan menyebarkan informasi di lingkup pertanian baik secara umum maupun khusus, penerbitan jurnal ini diharapkan dapat menjadi sarana untuk menampung tulisan-tulisan ilmiah pertanian.

Dewan redaksi mengucapkan terima kasih kepada semua pihak yang telah memerikan bantuan teknis maupun non teknis untuk terbitnya jurnal TriAgro ini. Dewan redaksi sangat mengharapkan partisipasi peneliti untuk menyumbangkan tulisannya ke jurnal TriArgro ini guna menjaga kelancaran penerbitan, yaitu dua kali setahun.

Dewan redaksi mengucapkan terima kasih kepada Bapak/Ibu/Saudara yang telah berpartisipasi pada jurnal edisi ini. Semoga Jurnal ini dapat memberikan manfaat kepada Bapak/Ibu/Saudara semuanya. 


\title{
RESPON EKSPLAN TANAMAN KENTANG (Solanum tuberrosum L.) VARIETAS GRANOLA TERHADAP DOSIS PUPUK DAUN DAN KONSENTRASI AIR KELAPA
}

\author{
RESPONSE EXPLANTS POTATO (Solanum tuberrosum L.) \\ VARIETIES GRANOLA AGAINST LEAF MANURE DOSE AND \\ CONCENTRATION OF COCONUT WATER.
}

\author{
${ }^{1}$ ROSTIAN NAFERY, ${ }^{2}$ ZULKARNAIN HUSNY, ${ }^{3}$ WENDRI PRANATA \\ ${ }^{12}$ Dosen Program Studi Agroteknologi, ${ }^{3}$ Mahasiswa Program Studi Agroteknologi \\ Program Studi Agroteknologi Fakultas Pertanian Universitas Tridinanti Palembang \\ Jl. Kapten Marzuki No.2446 Kamboja Palembang 30129
}

\begin{abstract}
Response Explants Potato (Solanum tuberrosum L.) Varieties Granola against Leaf Manure Dose and Concentration of Coconut Water. This study aims to find the right media formulation for plant propagation potato (Solanum tuberrosum L.) in vitro. Research conducted at the Tissue Culture Laboratory of the Faculty of Agriculture, University of Tridinanti Palembang began in May 2015 until July 2015. The study design used is experimental method Completely Randomized Design (CRD), with 5 (five) treatments and 5 (five) replicates as follows : $\mathrm{H}_{1}=\mathrm{MS}$ (controls), $\mathrm{H}_{2}=$ Hyponex $2 \mathrm{~g}$ per liter $+40 \%$ Coconut Water, $\mathrm{H}_{3}=$ Hyponex 2,5 g per liter $+40 \%$ Coconut Water, $\mathrm{H}_{4}=$ Growmore $2 \mathrm{~g}$ per liter $+40 \%$ Coconut Water, $\mathrm{H}_{5}=$ Growmore 2,5 g per liter $+40 \%$ Coconut Water. Each treatments was repeated 5 (five) times. Parameter observation that time formed buds, shoots, formed a root, root number, root length, and percentage of plantlets life. The results showed that treatment of $\mathrm{H} 2=$ Hyponex $2 \mathrm{~g}$ per liter $+40 \%$ Coconut Water can stimulate the growth of potato explants better and show the best result in the fastest time parameter 3,37 hst formed buds, shoots high $8,81 \mathrm{~cm}$, and number of roots 3,53 highest share.
\end{abstract}

Keyword: Explants Potato, Leaf Manure, Coconut Water.

\section{ABSTRAK}

Respon Eksplan Tanaman Kentang (Solanum tuberrosum L.) Varietas Granola terhadap Dosis Pupuk Daun dan Konsentrasi Air Kelapa. Penelitian ini bertujuan mencari formulasi media yang tepat untuk perbanyakan tanaman kentang (Solanum tuberrosum L.) secara in vitro. Penelitian dilaksanakan di Laboratorium Kultur Jaringan Fakultas Pertanian Universitas Tridinanti Palembang mulai bulan Mei 2015 sampai bulan Juli 2015. Rancangan penelitian yang digunakan adalah metode percobaan Rancangan Acak Lengkap (RAL), dengan 5 (lima) perlakuan dan 5 (lima) ulangan yaitu : $\mathrm{H}_{1}=$ MS (kontrol), $\mathrm{H}_{2}=$ Hyponex $2 \mathrm{~g}$ per liter + Air Kelapa $40 \%, \mathrm{H}_{3}=$ Hyponex $2,5 \mathrm{~g}$ per liter + Air Kelapa $40 \%, \mathrm{H}_{4}=$ Growmore $2 \mathrm{~g}$ per liter + Air Kelapa $40 \%, \mathrm{H}_{5}=$ Growmore 2,5 g per liter + Air Kelapa $40 \%$. Setiap perlakuan diulang 5 (lima) kali. Parameter pengamatan yaitu waktu terbentuk tunas, tinggi tunas, waktu terbentuk akar, jumlah akar, panjang akar, dan persentase plantlet hidup. Hasil penelitian menunjukkan bahwa perlakuan $\mathrm{H}_{2}=$ Hyponex 2 g per liter + Air Kelapa $40 \%$ dapat memacu pertumbuhan eksplan kentang menjadi lebih baik dan memperlihatkan hasil terbaik pada parameter waktu terbentuk tunas tercepat $3,73 \mathrm{hst}$, tinggi tunas tertinggi $8,81 \mathrm{~cm}$, dan jumlah akar terbanyak 3,53 lembar.

\section{PENDAHULUAN}

Kentang (Solanum tuberosum L.) merupakan sumber makanan terbesar keempat di dunia setelah padi, gandum dan jagung (Wattimena, 2000 dalam Nugroho, 2013).
Berdasarkan data Badan Pusat Statistik (BPS) Republik Indonesia (2015), produksi kentang di daerah Sumatera Selatan pada tahun 2013 adalah 2.823 ton, masih tergolong rendah apabila dibandingkan dengan produksi kentang 
di Bengkulu (12. 612 ton) dan Jambi (85.536 ton). Sebagian besar produksi tanaman kentang di Indonesia berasal dari kentang varietas Granola.

Kendala yang dihadapi petani kentang adalah sulitnya memperoleh umbi yang berkualitas tinggi. Usaha untuk meningkatkan produksi bibit kentang yang berkualitas dapat dilakukan melalui perbanyakan tanaman secara kultur jaringan (in vitro). Kultur in vitro merupakan salah satu teknik perbanyakan alternatif pada tanaman, tetapi pada saat ini perkembangan kultur in vitro di Indonesia terutama di Sumatera Selatan masih lambat jika dibandingkan dengan negara-negara lain. Salah satu penyebab teknologi ini sangat lambat perkembangannya adalah karena persepsi bahwa kultur in vitro merupakan teknik perbanyakan tanaman yang mahal seperti untuk membangun laboratorium kultur, alat-alat dan bahan kimia untuk media tanam sehingga teknologi ini hanya cocok untuk perusahaan besar (Nadapdap, 2000 dalam Seswita, 2010).

Salah satu cara untuk meminimalisir mahalnya biaya teknik perbanyakan ini adalah dengan mencari alternatif penggunaan bahan kimia pada media tanam eksplan. Media yang paling umum digunakan pada kultur in vitro adalah media Murashige dan Skoog (MS) yang mengandung hara makro, mikro dan vitamin lengkap, akan tetapi media MS harganya relatif tinggi. Pupuk daun mengandung unsur unsure hara yang lengkap sehingga dapat digunakan sebagai media alternatif untuk mendukung pertumbuhan dan perkembangan tanaman secara kultur in vitro.

Pupuk daun adalah pupuk buatan yang cara pemberiannya dilakukan melalui penyemprotan ke daun. Growmore adalah pupuk yang mengandung unsur hara makro dan mikro lengkap dengan kandungan Nitrogen yang tinggi. Berdasarkan hasil penelitian Nurheldi (2006) dalam Novi (2014), pengaruh komposisi media alternatif terbaik ditunjukkan oleh $\mathrm{M}_{2}$ (Growmore $2 \mathrm{~g}$ per liter + air kelapa $150 \mathrm{ml}$ per liter). Perlakuan $\mathrm{M}_{2}$ merupakan media alternatif yang dapat digunakan sebagai media pengganti media MS dalam kultur jaringan anggrek dendrobium, serta proses pembuatan media alternatif ini lebih mudah dan cukup ekonomis, karena bahan yang diperlukan untuk membuat media ini mudah didapatkan.

Pupuk daun selain Growmore yang dapat dicoba efektivitasnya sebagai bahan media dasar adalah Hyponex. Hyponex berpotensi sebagai media pengganti media MS karena memiliki kandungan unsur hara makro dan mikro yang berguna bagi pertumbuhan dan perkembangan tanaman. Pemberian Hyponex 1,5 g per liter yang dikombinasikan dengan air kelapa $30 \%$ menunjukkan hasil terbaik pada perbanyakan kultur in vitro kentang, peningkatan konsentrasi pemberian air kelapa diperkirakan akan semakin meningkatkan pertumbuhan (Nadapdap, 2000 dalam Seswita, 2010).

Menurut George (1993) dalam Kristina dan Syahid (2012), keberhasilan perbanyakan in vitro dipengaruhi oleh berbagai faktor diantaranya jenis media dasar yang digunakan, aplikasi Zat Pengatur Tumbuh (ZPT) yang tepat serta kondisi lingkungan kultur. Air kelapa merupakan senyawa organik yang sering digunakan dalam aplikasi teknik kultur jaringan. Air kelapa adalah air alami steril dengan kandungan unsur $\mathrm{K}$ dan $\mathrm{Cl}$ yang tinggi, selain itu air kelapa mengandung sukrosa, fruktosa, dan glukosa (Netty, 2002 dalam Kristina dan Syahid, 2012). Penambahan air kelapa ke dalam media kultur diharapkan dapat menggantikan ZPT sintetik golongan sitokinin sehingga biaya untuk perbanyakan tanaman secara kultur jaringan akan lebih ekonomis, disamping itu kandungan unsur-unsur hara dalam air kelapa dapat meningkatkan kandungan hara dalam media.

Berdasarkan uraian di atas, maka dalam penelitian ini perlu dicari formulasi pupuk daun dan konsentrasi air kelapa yang tepat, sehingga dapat digunakan sebagai pengganti media MS pada perbanyakan kentang varietas Granola secara in vitro.

\section{TUJUAN DAN KEGUNAAN PENELITIAN}

Tujuan dari penelitian ini adalah :

1. Mengetahui jenis formulasi pupuk daun yang dapat digunakan sebagai pengganti MS pada media perbanyakan tanaman kentang varietas Granola secara in vitro.

2. Mengetahui formulasi kombinasi pupuk daun dan konsentrasi air kelapa yang tepat, sehingga dapat digunakan pada perbanyakan tanaman kentang varietas Granola secara in vitro

Kegunaan dari penelitian ini diharapkan dapat bermanfaat bagi ilmu pengetahuan dan teknologi khususnya bagi peneliti selanjutnya dan sebagai informasi tentang alternatif media kultur jaringan (in vitro) khususnya pada tanaman kentang varietas Granola dalam penyediaan pada tingkat petani maupun pengusaha berskala luas. 


\section{BAHAN DAN METODE}

Penelitian ini dilaksanakan di Laboratorium Kultur Jaringan Program Studi Agroteknologi Fakultas Pertanian Universitas Tridinanti Palembang. Penelitian telah dilaksanakan dari bulan Mei 2015 sampai bulan Juli 2015. Bahan yang digunakan adalah plantlet kentang Varietas Granola, pupuk daun Hyponex dan Growmore, air kelapa, agar, gula putih, alkohol $70 \%$, formalin $50 \%$, betadine, spiritus, air mineral, dan detergen. Alat-alat yang digunakan dalam penelitian ini terdiri dari peralatan gelas (botol kultur, petridish, erlenmeyer, gelas ukur, gelas piala, labu takar, pipet, dan corong), autoklaf, laminar air flow, aluminium foil, timbangan analitik, oven listrik, kompor gas, kulkas, peralatan diseksi (pemotong) seperti pinset dan scalpel, gunting, bunsen, botol sprayer, pH meter, kertas label, dan karet gelang.

Penelitian ini dilakukan menggunakan Rancangan Acak Lengkap (RAL), dengan 5 (lima) perlakuan dan 5 (lima) ulangan. Setiap unit percobaan terdiri dari 5 (lima) botol kultur, sehingga diperlukan sebanyak 125 botol kultur. Perlakuan dalam penelitian ini yaitu $\mathrm{H}_{1}=\mathrm{MS}$ (kontrol), $\mathrm{H}_{2}=$ Hyponex $2 \mathrm{~g}$ per liter + Air Kelapa $40 \%, \mathrm{H}_{3}=$ Hyponex 2,5 g per liter + Air Kelapa $40 \%, \mathrm{H}_{4}=$ Growmore $2 \mathrm{~g}$ per liter + Air kelapa $40 \%, \mathrm{H}_{5}=$ Growmore $2,5 \mathrm{~g}$ per liter + Air kelapa $40 \%$. Peubah yang diamati adalah waktu terbentuk tunas (hari), tinggi tunas $(\mathrm{cm})$, waktu terbentuk akar (hari), jumlah akar (lembar), panjang akar $(\mathrm{cm})$, persentase plantlet hidup (\%).

Data hasil pengamatan yang diperoleh dianalisis secara statistik dengan menggunakan Analisis Keragaman Rancangan Acak Lengkap (RAL). Apabila dari hasil uji $\mathrm{F}$ diperoleh pengaruh yang nyata atau sangat nyata, maka dilanjutkan dengan uji beda antar perlakuan, digunakan uji tes BNT (Beda Nyata Terkecil).

\section{HASIL DAN PEMBAHASAN}

Hasil analisis keragaman terhadap semua peubah yang diamati tertera pada Tabel 1 berikut ini:
Tabel 1. Analisis Keragaman Semua Peubah yang Diamati

\begin{tabular}{|c|c|c|}
\hline Parameter Pengamatan & F Hitung & $\mathrm{KK}(\%)$ \\
\hline $\begin{array}{l}\text { 1. Waktu terbentuk } \\
\text { tunas (hst) }\end{array}$ & $1,14^{\text {tn }}$ & 5,03 \\
\hline 2. Tinggi tunas & $2,77^{\mathrm{n}}$ & 9,23 \\
\hline $\begin{array}{l}\text { 3. Waktu terbentuk } \\
\text { akar (hst) }\end{array}$ & $1,95^{\mathrm{tn}}$ & 4,88 \\
\hline 4. Jumlah akar & $0,65^{\mathrm{tn}}$ & 8,84 \\
\hline 5. Panjang akar & $3,24^{\mathrm{n}}$ & 4,63 \\
\hline $\begin{array}{l}\text { 6. Persentase hidup } \\
\text { tanaman }(\%)\end{array}$ & $1,09^{\text {tn }}$ & 19,02 \\
\hline F Tabel 0,05 & 2,67 & \\
\hline $\begin{array}{ll}\text { Keterangan : } \\
\mathrm{n} & =\text { Berpengaruh } \\
\mathrm{tn} & =\text { Berpengaruh } \\
\mathrm{KK} & =\text { Koefisien Ke }\end{array}$ & $\begin{array}{l}\text { ata } \\
\text { ak nyata } \\
\text { aman }\end{array}$ & \\
\hline
\end{tabular}

Hasil analisis keragaman pada Tabel 1 menunjukkan bahwa perlakuan pada parameter waktu terbentuk tunas, waktu terbentuk akar, jumlah akar, dan persentase hidup tanaman berpengaruh tidak nyata. Sedangkan perlakuan pada parameter tinggi tunas dan panjang akar berpengaruh nyata.

Berdasarkan hasil analisis keragaman pada Tabel 1 menunjukkan bahwa perlakuan berpengaruh tidak nyata terhadap parameter waktu terbentuk tunas, waktu terbentuk akar, jumlah akar, dan persentase plantlet hidup. Pertumbuhan dan perkembangan eksplan berkaitan dengan kemampuan organ tanaman dalam menyerap unsur hara, eksplan yang belum berdiferensiasi menjadi tanaman sempurna belum mampu menyerap unsur hara secara optimal. Menurut Harjadi (2002), pertumbuhan dan perkembangan tanaman diatur oleh zat organik yang dibentuk di berbagai bagian tanaman dan diangkut ke bagian lain. Golongan zat semacam itu yang disebut Zat Pengatur Tumbuh (ZPT).

Air kelapa mengandung sitokinin yang dapat merangsang perkembangan eksplan. Hasil pengamatan menunjukkan bahwa waktu terbentuk tunas lebih cepat daripada waktu terbentuk akar, tunas yang terbentuk memerlukan waktu 3 hst sampai 4 hst, sedangkan akar membutuhkan waktu 5 hst sampai 7 hst (Gambar 1). Menurut Wetherell 
(1982) dalam Trinawaty (2008) fungsi dari sitokinin adalah untuk merangsang pertumbuhan tunas tetapi dapat menghambat pertumbuhan dan perkembangan akar.

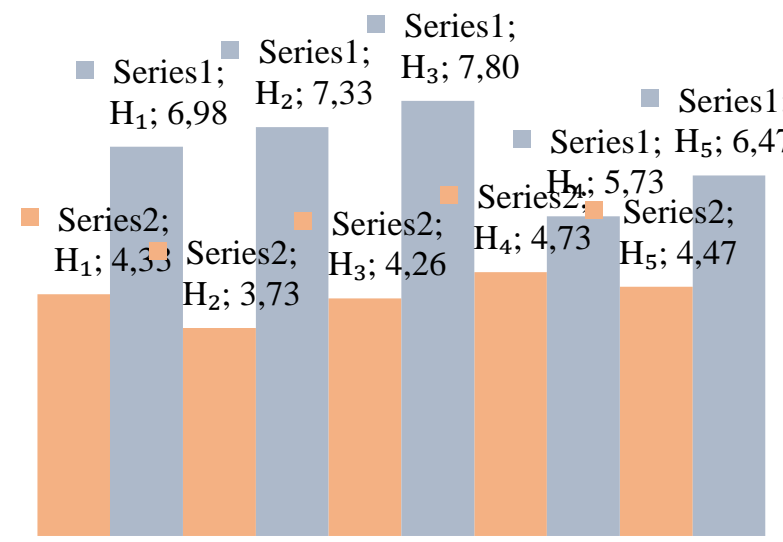

Waktu Terbentuk Akar

Waktu Terbentuk Tunas

Gambar 1. Pengaruh perlakuan terhadap waktu terbentuk akar dan waktu terbentuk tunas

Persentase plantlet hidup pada penelitian ini tergolong cukup tinggi, yaitu lebih dari $60 \%$. Tingkat kehidupan plantlet dipengaruhi oleh sterilisasi yang optimal. Sterilisasi adalah hal penting yang harus dilakukan untuk menghilangkan organisme yang menempel di permukaan eksplan yang dapat menyebabkan kontaminasi (Yusnita, 2003 dalam Trinawaty, 2008). Sebagian besar plantlet tidak dapat bertahan hidup akibat terkontaminasi oleh jamur dan bakteri. Perlakuan dengan persentase hidup tertinggi adalah $\mathrm{H}_{1}(\mathrm{MS})$ yaitu $88 \%$, sedangkan perlakuan lain yang memiliki persentase hidup kurang dari $88 \%$ (Gambar 2) adalah perlakuan dengan pemberian air kelapa.

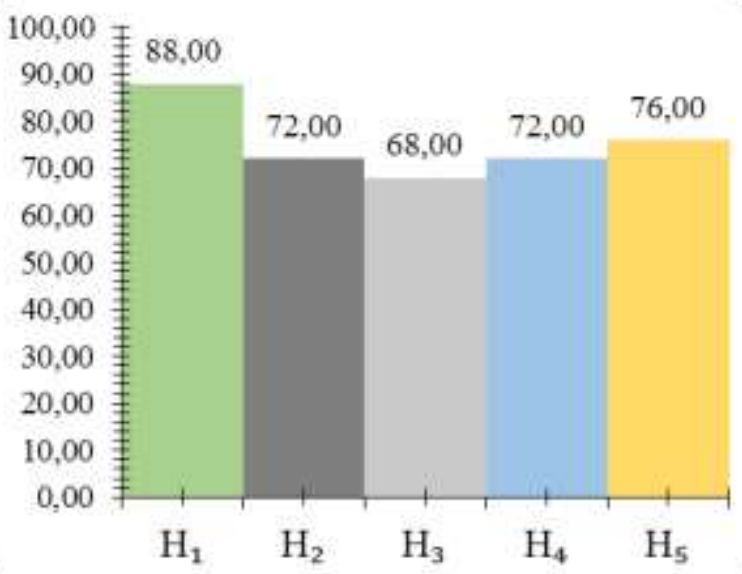

Gambar 2. Pengaruh perlakuan terhadap persentase plantlet hidup

Hasil analisis keragaman pada Tabel 1 menunjukkan bahwa perlakuan berpengaruh nyata terhadap parameter tinggi tunas dan panjang akar. Media dengan pelakuan $\mathrm{H}_{2}$ (Hyponex 2 g per liter + Air Kelapa 40\%) memberikan hasil terbaik dan berbeda nyata terhadap peubah tinggi tunas dibandingkan dengan perlakuan lainnya. Selain pengaruh dari sitokinin dalam air kelapa yang berperan penting dalam pembelahan sel dan diferensiasi sel serta bermanfaat juga untuk pertumbuhan pucuk tanaman (Warisno, 1998 dalam Darmawi, 2014) hal ini diduga pengaruh unsur $\mathrm{N}$ (Nitrogen) yang terkandung dalam pupuk daun yang berperan sebagai penyusun bagian vegetatif tanaman. Menurut Hanafiah (2012), Nitrogen merupakan unsur yang berperan menonjol terhadap bagian vegetatif tanaman (dedaunan dan pucuk). Fungsi Nitrogen dalam tanaman adalah sebagai komponen penyusun semua protein, klorofil dan asam-asam nukleat, serta berperan penting dalam pembentukan koenzim.

Tabel 2. Pengaruh Perlakuan terhadap Rata-rata Tinggi Tunas Plantlet Kentang.

\begin{tabular}{ccc}
\hline Perlakuan & Rerata & $\begin{array}{c}\text { Beda antar } \\
\text { perlakuan }\end{array}$ \\
\hline $\mathrm{H}_{4}$ & $4,57 \mathrm{~cm}$ & $\mathrm{a}$ \\
$\mathrm{H}_{5}$ & $4,99 \mathrm{~cm}$ & $\mathrm{a}$ \\
$\mathrm{H}_{3}$ & $5,62 \mathrm{~cm}$ & $\mathrm{a}$ \\
$\mathrm{H}_{1}$ & $5,66 \mathrm{~cm}$ & $\mathrm{a}$ \\
$\mathrm{H}_{2}$ & $8,81 \mathrm{~cm}$ & $\mathrm{~b}$
\end{tabular}

$\mathrm{BNT}_{0,05}=2,96$

Ket : Angka yang diikuti oleh hurup yang sama pada kolom yang sama tidak berbeda nyata pada taraf uji $5 \%$.

Media kultur yang diberi Hyponex dengan dosis 2,5 g per liter ditambah konsentrasi Air Kelapa 40\% $\left(\mathrm{H}_{3}\right)$ dan media MS $\left(\mathrm{H}_{1}\right)$ memberikan respon yang baik terhadap panjang akar dan berbeda nyata dibandingkan dengan perlakuan $\mathrm{H}_{4}$ dan $\mathrm{H}_{5}$ dan berbeda tidak nyata dengan perlakuan $\mathrm{H}_{2}$. Hal ini diduga pemberian hara pada media akan mempengaruhi perkembangan akar. Menurut Lakitan (2012), sistem perakaran tanaman dapat dipengaruhi oleh media tumbuh tanaman. Faktor yang mempengaruhi pola penyebaran 


\section{JURNAL TRIAGRO}

akar antara lain adalah ketersediaan unsur hara. Unsur P yang terkandung dalam pupuk daun diduga memicu perkembangan akar. Menurut Hanafiah (2012), suplai P yang cukup akan merangsang perkembangan system perakaran. Selain itu, dalam air kelapa juga terkandung auksin yang berfungsi merangsang pembelahan, pemanjangan sel, dan merangsang pembentukan akar (Abidin, 1985 dalam Trinawaty, 2008) sehingga dapat merangsang pemanjangan akar.

Tabel 3. Pengaruh Perlakuan terhadap Rata-rata Panjang Akar Plantlet Kentang.

\begin{tabular}{ccc}
\hline Perlakuan & Rerata & $\begin{array}{c}\text { Beda antar } \\
\text { perlakuan }\end{array}$ \\
\hline $\mathrm{H}_{5}$ & $2,04 \mathrm{~cm}$ & $\mathrm{a}$ \\
$\mathrm{H}_{4}$ & $2,11 \mathrm{~cm}$ & $\mathrm{a}$ \\
$\mathrm{H}_{2}$ & $2,87 \mathrm{~cm}$ & $\mathrm{abc}$ \\
$\mathrm{H}_{1}$ & $3,23 \mathrm{~cm}$ & $\mathrm{bc}$ \\
$\mathrm{H}_{3}$ & $3,34 \mathrm{~cm}$ & $\mathrm{bc}$ \\
\hline $\mathrm{BNT}_{0,05}=$ & & \\
1,01 & &
\end{tabular}

Ket : Angka yang diikuti oleh hurup yang sama pada kolom yang sama tidak berbeda nyata pada taraf uji 5\%.

\section{KESIMPULAN}

Berdasarkan hasil penelitian yang diperoleh maka dapat disimpulkan bahwa, perlakuan $\mathrm{H}_{2}$ (Hyponex 2 g per liter + Air Kelapa 40\%) memperlihatkan hasil terbaik pada parameter waktu terbentuk tunas tercepat $3,73 \mathrm{hst}$, tinggi tunas tertinggi $8,81 \mathrm{~cm}$, dan jumlah akar terbanyak 3,53 lembar pada plantlet kentang varietas Granola.

\section{SARAN}

Untuk mendapatkan hasil penelitian yang lebih baik perlu dilakukan penelitian lanjutan secara in vitro dengan media yang sama, dan dengan waktu yang lebih lama.

\section{DAFTAR PUSTAKA}

Badan Pusat Statistik. 2015. Produksi Tanaman Kentang Seluruh Provinsi. Badan Pusat Statistik Indonesia. Diakses di : http://www.bps.go.id/tab tanggal 13 Maret 2015.
Darmawi, M. 2014. Pengaruh Pemberian Zat Pengatur Tumbuh (ZPT) terhadap Pertumbuhan Stum Mata Tidur Karet (Hevea Brasiliensis Muell Arg. ) Klon IRR 112 (skripsi). Penelitian ini tidak dipublikasikan. Universitas Tridinanti Palembang. Palembang.

Hanafiah, K.A. 2012. Dasar-dasar Ilmu Tanah. Rajawali Pers. Jakarta. 359 hlm.

Harjadi, S.S. 2002. Pengantar Agronomi. Gramedia Pustaka Utama. Jakarta. $184 \mathrm{hlm}$.

Lakitan, B. 2012. Dasar-Dasar Fisiologi Tumbuhan. Rajawali Pers. Jakarta. $201 \mathrm{hlm}$.

Kristina, N.N. dan Syahid, S.F. 2012. Pengaruh Air Kelapa terhadap Multiplikasi Tunas in vitro, Produksi Rimpang, dan Kandungan Xanthorrhizol Temulawak di Lapangan. Jurnal Littri 18(3). Hlm. 125-134 (2010).

Novi, T.T. 2014. Respon Pertumbuhan Buah Naga (Hylocereus costaricensis) pada Media Gandasil dan Growmore secara in vitro (skripsi). Penelitian ini tidak dipublikasikan. Universitas Tridinanti Palembang. Palembang.

Nugroho, G. 2013. Pengaruh Merk dan Konsentrasi Pupuk serta Konsentrasi Sukrosa pada Medium Cair terhadap Induksi Kentang Varietas Margahayu (skripsi). Universitas Negeri Semarang. Semarang. Diakses di : http://lib.unnes.ac.id tanggal 14 Maret 2015.

Seswita, D. 2010. Penggunaan Air Kelapa sebagai Zat Pengatur Tumbuh pada Multiplikasi Tunas Temulawak (Curcuma xanthorrhiza Roxb.) in vitro. Jurnal Littri 16(4). Hlm. 135 - 140 (2009).

Trinawaty, M. 2008. Studi Pertumbuhan Tunas Seruni (Chrysanthemum morifolium Ram.) secara in vitro (skripsi). Penelitian ini tidak 
dipublikasikan. Universitas Sriwijaya. Indralaya. 